\title{
Skills, investment and exports from manufacturing firms in Africa*
}

\author{
Måns Söderbom ${ }^{+}$and Francis Teal
}

\section{WPS/2000-8}

May 2000

\begin{abstract}
It has been argued that Africa will not be able to export manufactures as it lacks the necessary skills. Without an ability to export there will only be an incentive to invest in the sector if domestic demand grows rapidly. Comparative data for four African countries - the Cameroon, Ghana, Kenya and Zimbabwe - shows that in the early 1990s investment in manufacturing remained very low. The micro evidence on manufacturing exports is wholly consistent with the macro in suggesting these are, for most African countries, negligible. An exception is Zimbabwe. The paper uses a longer time series from Ghana to ask how skills have impacted on manufacturing investment and exports in the 1990s. Two dimensions of skills are defined and measured. The first is that observable in the education and experience of the workforce. The second is the underlying efficiency with which the firm operates. The latter is shown to be a significant determinant of both investment and exports. These exports are relatively capital intensive; unskilled labour intensive exports remain negligible. Possible reasons for these outcomes are discussed.
\end{abstract}

Correspondence: Centre for the Study of African Economies, Department of Economics, Manor Road, Oxford, OX1 3UQ.

JEL Classification: O12, D24.

Keywords: African manufacturing, exports, investment.

*This paper draws on collaborative work undertaken by economists from Africa, Europe and North America who have worked on firm level data for the manufacturing sector in Africa. The data for the Ghanaian manufacturing sector used in this paper were collected by a team from the Centre for the Study of African Economies (CSAE), University of Oxford, the University of Ghana, Legon and the Ghana Statistical Office, Accra. The surveys over the period 1992-1994 were part of the Regional Program on Enterprise Development (RPED) organised by the World Bank. The questionnaire was designed by a team from the World Bank. We are indebted to Abigail Barr for comments on an earlier version of this paper. The research was undertaken as part of the Trade and Enterprise Research Programme funded by the Department for International Development of the UK. The CSAE is funded by the Economic and Social Research Council of the UK.

+ Måns Söderbom is the UNIDO Fellow at the CSAE. 


\section{Introduction}

The questions posed in the paper are important for the design of policies which will reverse Africa's poor economic performance. What are the factors which limit investment and exports from Africa's manufacturing sector? The growth of such exports has been a key component in the successful growth of the NICs. Does the poor performance of its manufacturing sector constrain the long run growth of African economies? The general question posed in this paper is the following: can policies which increase rates of manufacturing investment and exports improve Africa's growth rate in a manner which will significantly reduce poverty in the continent?

There has been a rapid expansion in micro data on Africa's manufacturing sector which this paper will review, and use, to answer the questions posed. This data refers to the $1990 \mathrm{~s}$ which is a period when many African economies had removed, or greatly reduced, the trade restrictions which had characterised their policies toward the industrial sector in the 1960s and 1970s. In the past decade and a half one of the countries on which there is extensive micro manufacturing data over time, Ghana, has radically changed its trade policy. We use this data to assess how manufacturing investment and exports have changed in the 1990s. To a lesser, but important, extent there have also been changes in the openness of Zimbabwe, a country which is the focus of another paper in this symposium [Wood and Jordan].

In this paper we consider a similar issue to that raised by Wood and Jordan: the role of skills in determining the performance of the manufacturing sector. Their approach is to consider the macro evidence and relate macro outcomes to differences in factor endowment and policy across countries, in their case Uganda and Zimbabwe. In section 2 we review the factors that may be important, at both the macro and micro level, in determining manufacturing exports. It is possible to argue that the focus in this paper on the manufacturing sector is to miss the most important fact about sub-Saharan Africa: it lacks a comparative advantage in manufacturing. Trade reform, if successful, will reduce manufacturing output and increase the exports of natural resource intensive goods. Manufactured exports may rise but this will be a side-show of a side-show in terms of the overall impact of trade liberalisation. That certainly is the implication of the macro analysis. One contribution of this paper is to ask if the micro data confirms, contradicts or qualifies this conclusion. An area in which qualification may be important is in the possible growth of unskilled labour intensive manufactured exports. As we have seven years of micro data for the country with the longest period of trade liberalisation, Ghana, we can address this issue of the skill composition of manufacturing exports very directly. ${ }^{1}$

The micro evidence on the determinants of both manufacturing investment and exports is considered in sections 3 and 4 . We review comparative data across four countries - Ghana, the Cameroon, Kenya and Zimbabwe - before turning to the consideration of the longer time period which is available for Ghana. Skills are a potentially important determinant of both investment and exports. Two dimensions of skills are identified and measured in this paper. The first, which we summarise as human capital, is directly observable with our data; the education and experience of the workforce. The second is the underlying efficiency with which the firm operates. Such technical efficiency, which depends on such factors as managerial ability and effort, cannot be directly observed but it can be measured as a residual from a production function. ${ }^{2}$ The relationship between skills, investment and exports is complex. Both dimensions of skills should increase the return on physical capital and thus the incentive to invest. If human capital is scarce in Africa we should expect exports to use relatively little

${ }^{1}$ The major period of trade liberalisation in Ghana was from 1985 to 1991, see Alderman [1991]. The 1990s can be viewed as a period when the effects of this trade liberalisation should be observable.

${ }^{2}$ In this paper we treat the residuals from a constant returns to scale Cobb-Douglas production function as a measure of efficiency. Such a procedure labels as "efficiency" the combined effects on underlying productivity of scale, share and residual effects, see for example Tybout and Westbrook [1995]. As we are primarily concerned with how the underlying efficiency of a firm affects investment and exports we do not seek to distinguish between these components of efficiency. For brevity we term all these effects technical efficiency. 
of it. However, if only relatively efficient firms can export, we would expect our second dimension of skills, the underlying efficiency with which the firm operates, to be an important determinant of the decision to export. If the two dimensions of skills are positively correlated then the sign of the effect from skills generally to exporting is uncertain. The micro data enable these issues to be assessed in a detail that is not possible with macro data. We find that technical efficiency does play some role in the decision to export and that Ghanaian manufacturing exports are concentrated in relatively capital intensive firms. In section 5 we examine how the pattern of exporting in other African countries compares with that for Ghana. We summarise the argument of the paper in section 6, and return to our basic question, by asking what factors determine performance in Africa's manufacturing sector.

\section{Trade, Factor Endowment and the Manufacturing Sector in Africa}

Trade and exchange rate liberalisation have been central to the structural adjustment programmes implemented by most countries in sub-Saharan Africa since the 1980s. The policy measures have included the elimination of non-tariff barriers to imports, the rationalisation and reduction of tariffs, the institution of market determined exchange rates and the removal of fiscal disincentives and regulatory deterrents to exports. If coupled with fiscal and monetary discipline, appropriate financial sector reforms and the decontrol of domestic prices, such measures are expected to improve trade performance. Policies of this form have, to various extents, characterised all the countries on which we wish to focus.

The links between such trade reform and investment in the manufacturing sector are of importance for several reasons. A key rationale for the protective policies of the 1960s and 1970s was the belief by African governments that only with such protection would their manufacturing sectors be able to grow. One part of their reluctance to liberalise has been the perception that such liberalisation would lead to a contraction of manufacturing output and employment; the reasons for this view are considered below. In so far as the impact of trade liberalisation is concentrated in natural resource and mineral sectors such trade reform will not lead to the growth in employment opportunities which are seen as a key element in a successful reform process. There is also a view that learning externalities are important for manufacturing exports in a way that they are not for more traditional exports. If this view is correct then, if trade liberalisation could lead to increases in manufacturing investment and exports, the long run benefits for growth would be substantial. In contrast, if trade liberalisation leads to a contraction of manufacturing, the perception of policy-makers within Africa is that the policy promises a return to a colonial era where exports of agricultural products were exchanged for manufacturing imports. An important contribution of the Wood and Jordan paper is to qualify such an interpretation given the past relative success of Zimbabwe in exporting manufactures. For all these reasons it seems important to know what factors determine the performance of the manufacturing sector in Africa.

The Heckscher-Ohlin-Vanek (HOV) model predicts a mapping from factor endowments to trade patterns. If this comparative advantage model is correct then exports should be concentrated in the sectors which use the relatively abundant factor intensively. In the original HOV model the distinction drawn was between labour and capital intensive goods. The view that this is not the appropriate categorisation has been argued by Wood who has advanced two different models. The first is that NorthSouth trade can be analysed by assuming that capital is a traded good and that it is the endowments of skilled and unskilled labour which are the key determinants of comparative advantage, Wood [1994]. In this model Africa would be able to export manufactures in so far as it was relatively well endowed with unskilled labour. Africa is well endowed with both unskilled labour and natural resources, relative to skilled labour. In his second model Wood argues that it is the low levels of skills relative to natural resources that explain low manufacturing exports and the dominance of natural resource intensive goods in its exports, Wood and Berge [1997], Wood and Mayer [1998], Wood and Jordan [this issue]. It is possible that natural resource intensive economies will have a comparative advantage in processing primary products; essentially if transport costs are sufficiently high to outweigh the cost disadvantage. Owens and Wood [1997] find that the conclusion that SSA has a comparative disadvantage in a narrowly 
defined range of manufacturing exports also applies to a wider definition which includes the processing of primary products.

Whichever model is used the prediction is clear: Africa cannot expect to export skill intensive goods. However it clearly remains an open question as to whether, within the context of an HOV analysis, Africa can export unskilled labour intensive goods within manufacturing.

In contrast to the comparative advantage theory of export structure is the view that firm-level factors are important determinants of the ability to export, see for example Krugman, [1984 and 1987] and Grossman and Helpman [1991]. Exposure to world prices through trade reform generates a process of competitive selection which firms might not survive if they owe their existence largely to previously sheltered markets or subsidised input supplies. However the same process should raise productive and allocative efficiency among survivors and new entrants to industries. This in turn should lead to efficiency in import substitution and greater production for export markets, the larger size of which means greater scope for scale economies and firm growth than domestic markets have been able to offer so far. This view implies that increasing efficiency is the key to firms being able to enter the export market. Such efficiency may be linked to the observable skills the firms possess; the amount of education and tenure of the workforce. Efficiency may, on the other hand, be linked to unobservable factors: managerial ability, effort and enterprise. The relative importance of these two dimensions of skills can be assessed from micro data and will be the focus of our modelling of both investment and exports in the following sections.

The HOV model in its simplest form specifies a common production technology across a sector and makes no allowance for firm level heterogeneity. The empirical issue, that only micro data can investigate, is how far this assumption, which is clearly not literally true, matters for the purposes of understanding what limits the growth of Africa's manufacturing exports. Are there firms which are sufficiently efficient to be able to export manufactures? Is there evidence from Ghana that over the longer term there has been a rise in such exports? Are the exports that have occurred unskilled-labour intensive ones? Has investment been higher in sectors oriented towards exporting?

\section{Skills as Determinants of Manufacturing Investment in Africa}

For four countries - the Cameroon, Ghana, Kenya and Zimbabwe - we have detailed micro evidence on both investment and exports in their manufacturing sector in the early 1990s. All these countries have introduced some form of trade reforms in the early 1990s with the objective of reversing the poor economic performance up to the $1980 \mathrm{~s}$. We consider the evidence for investment in this section and that for exports in the next.

Figures for manufacturing investment are presented in Bigsten et al. [1999b, Table 4]. The rates of investment are very low. For only one country - Zimbabwe - is the median rate of investment greater than zero. The average rate of investment across all the countries is close to 11 per cent. This divergence between the median and mean is due to investment being concentrated in relatively few firms. There is little difference in mean investment rates across firms of different size so while the surveys over-sample large firms there is no reason to think the survey averages misleading for the population. Thus the micro evidence strongly suggest that, at least in the early 1990s, investment levels were very low.

It might well be argued that in only one of these countries, Ghana, has there been any credible long term commitment to reform. There is a longer run of data for Ghana and it is of interest to ask, over this longer term, if there is evidence for any rise in investment and exports within the manufacturing sector. If so it would be an important qualification for the finding of the comparative micro work which is confined, at present, to data for the early 1990s.

Table 1 presents the evidence from the firm-level surveys for the extent of manufacturing investment in Ghana over the period from 1993 to 1997 by year, sector and by whether or not the firm 
exports. ${ }^{3}$ Both investment to value-added and investment to capital are lower at the end than the beginning of the period. In fact the investment to capital rate is the lowest of any year of the survey in 1997. There is no evidence at all of any rise in investment rates over this period, if anything there is decline. The finding in Bigsten et al. [1999b] across four countries for the early 1990s - the Cameroon, Ghana, Kenya and Zimbabwe - that a substantial proportion of firms carry out no investment in any year is confirmed for this longer run of data. On average less than half of the firms in Ghana carry out any investment and in 1997 the percentage investing had fallen to 35 per cent. The proportion of firms carrying out any investment was highest in the wood sector and lowest in garments. The propensity to invest appears to be a function of firm size. Defining large firms as those with more than 100 employees the proportion of such firms carrying out any investment is more than twice that for micro firms where the latter are defined as those with fewer than 6 employees. Investment to value-added also appears to be much higher for the larger firms.

What is the role of skills in determining this outcome for investment in physical capital? We now use the relatively long run of data from Ghana to investigate this question. In the last section we noted that skills have at least two dimensions, the observable amount of human capital employed by the firm and the unobservable element which reflects the underlying efficiency with which the firm operates. The fact that the Ghana survey is a panel enables us to provide an empirical counterpart to this unobservable element. Table 2 reports the production function:

$$
Y_{i t}=A_{i t} K_{i t}^{\alpha} L_{i t}^{\beta} H_{i t}{ }^{\eta}
$$

where $\mathrm{K}$ is physical capital, $\mathrm{L}$ is the labour input and $\mathrm{H}$ is human capital which is measured by the average education and tenure of the workforce. ${ }^{4}$ Output, $\mathrm{Y}$, is measured as real value-added and we impose constant returns to scale. In Table 2 two equations are reported. The first includes whether or not the firm exports as a determinant of productivity. This has been done to establish whether for Ghana over this period there is a positive correlation between underlying productivity and exporting. Table 2 equation [1] confirms that exporting firms are some 24 per cent more efficient than firms which do not export, although this is only significant at the 10 per cent level. The issue which will be addressed in section 4 is whether there is evidence that causality runs from firm efficiency to the decision to export. In Table 2 equation 2 we report the regression the residuals from which will provide our measure of technical efficiency, ie the unobservable component of skills. It will be noted from this regression that firms with some foreign ownership are 31 per cent more efficient than other firms. The results also show a non-linear relationship between firm efficiency and age, with efficiency rising with age until firms are 33 years old. Levels of efficiency are lowest in the garment sector.

The marginal productivity of capital, $\mathrm{Y}_{\mathrm{K}}$, is given by:

$$
\text { (2) } Y_{i K}=A_{i t} \alpha K_{i t}^{\alpha-1} L_{i t}^{\beta} H_{i t}^{\eta}
$$

We can interpret our two measures of skills as factors that increase the marginal productivity of capital and thus provide the firm with an incentive to undertake some investment. Firms with higher skills may also face lower costs of adjustment in undertaking investment. The firm will undertake some investment if the returns from investment less the costs of adjustment are above some required return on investment

\footnotetext{
${ }^{3}$ The data is confined to the period over which the investment equation is estimated. Investment refers to capital expenditure on plant and equipment only.

${ }^{4}$ See appendix for details on how the human capital variables are measured.
} 
as in Pattillo [1998]. We do not formally model this decision but assume, initially, that all the factors which determine the amount of investment also affect whether to carry out any investment. ${ }^{5}$

Bigsten et al. [1999b] in their comparative study show that a flexible accelerator performs at least as well as the Euler specification of an investment function, once attention is confined to the amount of investment undertaken. We therefore adopt the following form of the flexible accelerator as our model of investment:

$$
\text { (3) } \frac{I_{i t}}{K_{i(t-1)}}=\alpha_{0}+\alpha_{1} \frac{I_{i(t-1)}}{K_{i(t-2)}}+\alpha_{2} \frac{\Delta Y_{i t}}{K_{i(t-1)}}+\alpha_{3} \frac{C_{i t}}{K_{i(t-1)}}+\alpha_{4} \frac{B_{i(t-1)}}{K_{i(t-1)}}+\alpha_{5} \text { Ln } A_{i t}+\alpha_{6} \text { Ln } H_{i(t-1)}
$$

where $\Delta \mathrm{Y} / \mathrm{K}_{(\mathrm{t}-1)}$ is the change in value-added, $\mathrm{C} / \mathrm{K}_{(\mathrm{t}-1)}$ is the cash flow variable and $(\mathrm{B} / \mathrm{K})_{(\mathrm{t}-1)}$ is the total borrowing of the firm, all deflated by the capital stock. $\mathrm{A}_{\mathrm{it}}$ is the measure of technical efficiency obtained as a residual from equation (2). In adopting this specification we are able to assess if this longer run of data for Ghana qualifies in any way the results derived by Bigsten el al. [1999b] for a much shorter period. In the context of a flexible accelerator model we would not expect a direct impact from skills, the technical efficiency and human capital terms in (3), onto investment once we control for changes in output and cash flow.

Table 3 equation [1] is a probit on whether the firm carries out any investment. Large firms are far more likely to invest, younger firms are no more likely to invest than older firms and there is an unexplained significant shift down in the propensity to invest in the final period of the survey. There is evidence from the earlier rounds of the survey, Pattillo [1998], that irreversibility and uncertainty play a part in the decision as to whether to invest. Our focus of interest here is on the role of skills in determining investment. The observable components of human capital, the education and tenure of the work force, do not have any significant positive impact on whether to invest. In fact the tenure variable enters with a significant negative coefficient. A possible explanation for this result is that firms which invest hire new employees thus reducing average tenure. If that is correct then tenure is an endogenous variable jointly determined with the investment decision; a similar result can be found in Söderbom [2000]. In contrast the unobservable element, the technical efficiency with which the firm operates, is a highly significant determinant of investment. In Table 3 equations [2] and [3] we control firstly for random effects in the probit and we then run a fixed effects logit. For all the specifications the measure of technical efficiency is a significant determinant of the decision to invest.

We turn now to the factors determining the amount of investment, conditioned on undertaking any investment. We report three specifications. The first, Table 4 equation [1], repeats the specification of the probit equation with the inclusion of the lagged dependent variables. Equation [2] allows for possible selectivity bias and excludes size and technical efficiency as means of identifying the selection correction factor. Equation [3] allows for fixed effects. There is some evidence from equation [2] that allowing for selectivity reduces the significance of the lagged dependent term. We drop the lagged dependent term for the fixed effects estimation. ${ }^{6}$ We find that neither dimension of skill has a significant positive impact in any of the specifications. The coefficient on tenure again enters with a negative sign consistent with the explanation already advanced that this variable should be regarded as endogenous. Once fixed effects are allowed for there is no significant effect from debt onto the amount of investment.

\footnotetext{
${ }^{5}$ Modelling the decision to invest is complex. A general model of how both fixed costs of investment and irreversibility may create conditions in which zero investment is optimal can be found in Abel and Eberly [1994]. Formally testing the model requires either information on the market valuation of the firm or direct measures of adjustment costs, neither of which are available in our data.

${ }^{6}$ If we had not dropped the lagged dependent term then it would have been necessary to allow for the bias in the coefficient caused by the correlation between the lagged dependent term and the fixed effect. This would have required the use of instruments which we have not attempted. Estimation of Table 4 equation [3] including the lagged dependent term produced no change in the coefficients reported in the Table and the lagged dependent term was not significant.
} 
By far the most robust and significant variable is cash flow the coefficient for which, from this seven years of data, is identical to that found in the data set used by Bigsten et al. [1999b] covering three years across four countries. While there is a significant effect of cash flow onto investment the effect is small and this result does not appear to be due to the relatively short period in the Bigsten et al. [1999b] analysis.

In summary we find strong evidence that more technically efficiency firms are far more likely to carry our some investment so this dimension of skills appears to be very important for understanding investment behaviour in the Ghanaian manufacturing sector. In contrast neither observable measure of human capital, the education of the work force or their tenure, impacts positively on investment. There is also a result common across both dimensions of the investment decision that exporting firms are not more likely to be undertaking investment.

\section{The Skill Composition of Manufacturing Exports from Africa}

Comparative evidence for manufacturing exports from the Cameroon, Ghana, Kenya and Zimbabwe is presented in Bigsten et al. [1999a]. The levels of manufacturing exports found from the surveys was very low and entirely consistent with the macro data summarised in Wood and Mayer [1998]. Across all the firms surveyed 31 per cent were exporting and, if they exported, they exported 26 per cent of their output. An important finding of these papers was that large firms, defined as those employing more than 100 persons, were much more likely to be exporters. So the survey averages, which over-sample large firms, greatly over-state the extent of exporting from the manufacturing sector.

Bigsten et al. [2000] have examined the links between exporting and firm efficiency for the same countries. They find that firms which export have higher efficiency and there is evidence that the causation runs both ways. More efficient firms are more likely to enter the export market and, once in the export market, the efficiency of such firms rises. Again their data covers only three years so longer runs effects cannot be established. In this section we propose to use the longer run of data from Ghana to extend the comparative data analysis in two respects. First, we allow for a richer dynamic structure for the mechanisms determining export participation, focussing explicitly on the decision to enter and exit the export market. Second, we examine the role of the two dimensions of skills identified in section 2 as determinants of export participation.

The export data for Ghana is presented in Table 5. There is over the period an increase in exporting activity, as the percentage of firms exporting has risen from 9 per cent in 1992 to 22 in 1997 and the percentage of output exported has increased from 3 per cent in the 1992 survey to 11 in 1997. As the Ghanian survey has progressed the number of large firms in the survey has risen so to assess this finding it is necessary to control for size which we do in the logits reported below. Across sectors it will be noted that firms in the wood sector are far more likely to be exporting than firms in other sectors, while the least export oriented sector is garments. With the exception of the wood sector the proportions of output exported from all other sectors was less than 10 per cent. Finally we note, a fact we have already referred to, that most exporting is done by large firms, those employing more than 100 workers.

We show in Table 6 descriptive statistics for the estimation sample of the patterns of exporting entry and exit during the period. Clearly, the rate of entry into exporting is low, with the average entry rate across the sample being only 4 per cent. The exit rate is higher at 21 per cent, although as this is conditioned on being an exporter the number of exits is low. On aggregate there was a modest net entry into exporting during the period.

A number of micro studies have shown that export participation normally exhibits strong state dependence, i.e. that the firm's history of exporting is important in determining contemporaneous participation; Roberts and Tybout [1997], Clerides et al. [1998], Bernard and Jensen [1999], and Bigsten et al. [2000]. One commonly proposed explanation for this is that firms face significant fixed costs to entering the exports market, due to bureaucratic procedures, the establishment of new marketing channels, and the need for a certain minimal size to meet export orders. If this is the case, policies which 
are successful in facilitating enough firms to enter the foreign market will have effects on exports extending over several time periods.

In order to understand the factors which determine the participation of firms in the export market we need to model whether a firm changes its exporting status between any two periods, either by making a transition from non-exporting to exporting (i.e. entry) or in the reverse direction (exit). Assuming that these transition probabilities can be specified as logistic functions, and conditioning on the exogenous variables, $\mathrm{x}_{i t}$, a firm specific random effect, $\mu_{i}$, and the previous state, $y_{i, t-1}$, we write the probability of entry as

$$
\operatorname{Pr}_{i t}^{\text {entry }} \equiv \operatorname{Pr}\left(y_{i t}=1 \mid x_{i t}, \mu_{i}, y_{i t-1}=0\right)=\frac{\exp \left(\alpha_{0}+\alpha^{\prime} x_{i t}+\mu_{i}\right)}{1+\exp \left(\alpha_{0}+\alpha^{\prime} x_{i t}+\mu_{i}\right)},
$$

and the probability of exit as

$$
\operatorname{Pr}_{i t}^{\text {exit }} \equiv \operatorname{Pr}\left(y_{i t}=0 \mid x_{i t}, \mu_{i}, y_{i t-1}=1\right)=\frac{\exp \left(\beta_{0}+\beta^{\prime} x_{i t}+\gamma \mu_{i}\right)}{1+\exp \left(\beta_{0}+\beta^{\prime} x_{i t}+\gamma \mu_{i}\right)},
$$

where $y_{i t}=1$ if there is some exporting, 0 if there is not;

$\alpha_{0}=$ intercept in the entry equation;

$\alpha=$ vector of slope coefficients in the entry equation;

$\beta_{0}=$ intercept in the exit equation;

$\beta^{\prime}=$ vector of slope coefficients in the exit equation; and

$\gamma=$ factor loading. ${ }^{7}$

By the total probability rule,

and

$$
\operatorname{Pr}_{i t}^{\text {non-entry }} \equiv \operatorname{Pr}\left(y_{i t}=0 \mid x_{i t}, \mu_{i}, y_{i t-1}=0\right)=1-\operatorname{Pr}_{i t}^{\text {entry }}=\frac{1}{1+\exp \left(\alpha_{0}+\alpha^{\prime} x_{i t}+\mu_{i}\right)},
$$

$$
\operatorname{Pr}_{i t}^{\text {non-exit }} \equiv \operatorname{Pr}\left(y_{i t}=1 \mid x_{i t}, \mu_{i}, y_{i t-1}=1\right)=1-\operatorname{Pr}_{i t}^{\text {exit }}=\frac{1}{1+\exp \left(\beta_{0}+\beta^{\prime} x_{i t}+\gamma \mu_{i}\right)}
$$

The transition model outlined in (4)-(7), which is similar to that used by Moon and Stotsky [1993], is attractive because it is flexible and because it nests a number of more familiar models. For instance, in the special case where there is no unobserved heterogeneity (so that the variance of $\mu_{i}$ is zero), $\alpha_{0}=-\beta_{0}$, and $\alpha^{\prime}=-\beta^{\prime}$, the standard cross-section logit model results. One way to see this is by using these equalities in (7), the probability of not exiting from exporting:

$$
P r_{i t}^{\text {non-exit }}=\frac{1}{1+\exp \left(-\alpha_{0}-\alpha^{\prime} x_{i t}\right)}=\frac{\exp \left(\alpha_{0}+\alpha^{\prime} x_{i t}\right)}{1+\exp \left(\alpha_{0}+\alpha^{\prime} x_{i t}\right)}
$$

In this case the probability of non-exit, ( 7 ), is equal to the probability of entry, (4), and thus the export participation decision depends only on observable exogenous variables while it is independent of past exporting experience:

$$
\operatorname{Pr}\left(y_{i t}=1 \mid x_{i t}, y_{i t-1}=1\right)=\operatorname{Pr}\left(y_{i t}=1 \mid x_{i t}, y_{i t-1}=0\right)=\operatorname{Pr}\left(y_{i t}=1 \mid x_{i t}\right) .
$$

${ }^{7} \gamma$ is a coefficient that enables the variance of the random effect to differ between the entry and exit logits. For computational ease the random effect is assumed to be uncorrelated with the exogenous variables in the model. In principle one can avoid this potentially restrictive assumption by using a fixed effects approach. In practice, however, this would not be feasible with the data at hand as the cross-section dimension is small, the length of the panel is short, and the number of explanatory variables we wish to include is quite large. 
Hence, in this special case it would be appropriate to estimate the model using a cross-section logit with a dummy variable for whether or not the firm exports as the dependent variable. Similarly, it can be shown that relaxing the restriction $\alpha_{0}=-\beta_{0}$, but retaining $\alpha^{\prime}=-\beta^{\prime}$, leads to the logit model with a lagged dependent variable:

$$
\operatorname{Pr}\left(y_{i t}=1 \mid x_{i t}, y_{i t-1}\right)=\frac{\exp \left(\alpha_{0}+\delta y_{i, t-1}+\alpha^{\prime} x_{i t}\right)}{1+\exp \left(\alpha_{0}+\delta y_{i, t-1}+\alpha^{\prime} x_{i t}\right)},
$$

where $\delta=-\left(\alpha_{0}+\beta_{0}\right)$. Clearly, if $\delta>0(\delta<0)$ this model exhibits state dependence in that past exporting increases (decreases) the probability of exporting in the current period. Note however that this effect stems only from a shift in the intercept. By going one step further, relaxing the restrictions on the slope parameters of the model as well, we can allow for a richer structure of state dependence in that the impact of exogenous variables will depend on past exporting status. Such asymmetry will arise if the effect on the entry decision of, say, a positive shock to efficiency is different to the effect on the exit decision of a negative efficiency shock of the same magnitude. Finally, amending the random effects, which will enter the model in the same manner as the exogenous variables, we arrive at the model (4)-(7).

In our econometric models we include as explanatory variables observable human capital, the level and the change in technical efficiency, and capital intensity, measured as the logarithm of the capital to employment ratio. This enables us to consider the issue, raised in Section 2 above, as to whether Africa has been able to export unskilled labour intensive manufactures. Recall from our previous discussion that skills may impact on exporting in two ways. If a country is relatively well endowed with unskilled labour then we would expect exporting to be concentrated in firms with low capital (both physical and human) per employee. The underlying causal mechanism that would lead from these factor proportions to the firm-level decision to export would be the link from macro factor endowments to factor pricing. Alternatively skills may enhance the efficiency of the firm and so be positively associated with exporting.

To control for the fact that fixed costs deter mainly small firms from entering into exports, we include the logarithm of employment as an explanatory variable. Expecting the marginal propensity to export to vary with firm age, due to, say, the recent trade liberalisation affecting the trade incentives of old and young firms differently, we allow for a non-linear impact of firm age. Finally, we include control variables for sector, time, and ownership.

Table 7 shows the results of logit regressions modelling export participation under various assumptions. The first column reports the results from a model where the decision to export is assumed to be state independent and where unobserved firm effects are assumed absent. ${ }^{8}$ The regression indicates that firms with high physical capital per employee are significantly more likely to export than more labour intensive firms. There appears to be a positive association between technical efficiency, represented by the residuals from the production function, and exporting. However the coefficient is only significant at the 10 per cent level, and it is quite possible that the coefficient is upward biased since we have not accounted for potential endogeneity. Education and tenure, which measure the observable skill dimension, are not significantly affecting exporting. The dummy variable for the wood sector has a very large and highly significant coefficient, indicating that exporting is concentrated to the wood sector for reasons that go beyond heterogeneity in factor endowments and other observable firm characteristics. Export activity is low in the garment sector where labour intensity is high. We obtain a pronounced nonlinearity in the relation between firm age and exports participation, where the exporting probability increases up until the age of 16 years, and then falls. This non-linear effect is significant at the 1 per cent level. Finally, the coefficient on employment is positive and significant at the 1 per cent level. This is consistent with a situation in which there are fixed costs of exporting.

\footnotetext{
${ }^{8}$ Given the structure of the data reported in Table 5, this non-dynamic specification is likely to be a mis-specification, but we feel it is useful as a benchmark and because this modelling strategy has been used in previous work [Bigsten et al., 1999a].
} 
How are these results affected when we allow the factors determining entry to differ from those determining exiting? Model [2] does not control for unobserved heterogeneity, whereas Model [3] does. Attempting to keep the number of parameters within reasonable limits, we started by estimating the general model without any restrictions on the parameters, and tested for symmetry restrictions on the parameters in the entry and exit equations. In the cases where we could not reject the hypothesis that the coefficients were mirror images of each other at the 20 per cent level, we imposed the restriction. ${ }^{9}$ Employment and capital intensity affect entry and exit symmetrically, and their coefficients are similar in magnitude to their counterparts in Model [1]. Both coefficients are statistically significant. We find state dependence in the way human capital, as measured by the level of tenure, affects export participation, as the tenure coefficient is negative in both equations. In the entry equation the coefficient is significant at the 5 per cent level, and we can reject the hypothesis that there is no state dependence (i.e. that the coefficients are mirror images of each other) at the 10 per cent level (the p-value is 0.054 ). The fact that tenure is negative and significant in the entry model may be the result of a similar endogenity problem to that observed between tenure and investment. If firms which enter the export market need to make changes which include employing new workers then tenure will fall with the decision to export. The other measure of human capital, education, is insignificant and is likely to be exogenous in a way that tenure is not.

Recall from Model [1] that we obtained a fairly low and only marginally significant coefficient on technical efficiency. However, the results in the Model [2] show that this was a result of incorrectly assuming the efficiency coefficient to be state independent. Whereas the coefficient in the entry equation is very small, and far from significant, the magnitude of the coefficient in the exit equation is more than five times larger than the coefficient in Model [1], and significant at the 5 per cent level. Further, we can reject the hypothesis of no state dependence in the efficiency coefficient at the five per cent level. This is rather a striking result: whereas efficiency usually is thought to increase overall exporting activity through its positive effects on entry, our results indicate that efficiency is unimportant for entry but of considerable importance for the exit decision. Whether this is because exporting is a marginal activity of the firm, so that the decision to remain as an exporter is sensitive to changes in the firm's business environment, or due to some other mechanism cannot be determined at this stage. What is clear however is that the relation between efficiency and the incentives for exporting is complex.

It was found in Model [1] that the wood sector was dominating exporting activity. When we unpack the coefficient on the wood dummy in Model [2], we see that this effect stems completely from wood sectors being much more inclined to enter into exporting; in the exit equation, the wood coefficient is practically zero. Further, it is clear that the non-linear age effect only applies for entry. In the exit equation, the age coefficients are jointly insignificant, whereas they are highly (jointly) significant in the entry equation. In the latter, the point estimates imply that the probability of entry peaks at the age of 27 years and then falls. We can reject the hypothesis of no state dependence in the age effect at the 1 per cent level.

One shortcoming of Model [2] lies in its failure to control for unobserved firm specific heterogeneity, stemming from, for instance, differences in managerial ability. Unfortunately, in dynamic models the omission of permanent firm effects will lead to biased and inconsistent estimates even if the firm effects are uncorrelated with the strictly exogenous variables in the model. To address this issue, we adopt a random effects approach as discussed above. Specifically, to integrate the random effect out of the model, we follow Bigsten et al. [2000] and Mroz [1999] and approximate its distribution by a step function. Because the panel is short, we have an initial conditions problem which we deal with by using a non-parametric approach as suggested by Arellano and Carrasco [1999]. We refer the interested reader to the above references for more on the econometric details, and do not comment further on them here. In what follows we shall also not report the estimated parameters of the heterogeneity distribution, but they are available on request. Results of the random effects model are reported in Table 7 Model [3].

\footnotetext{
${ }^{9}$ In the table, the restricted coefficients can easily be spotted as they do not have z-statistics attached to them in the exit equations.
} 
Allowing for random effects does not have an important effect on any of the results documented in Model [2]: large, capital intensive firms are more likely export both due to higher entry rates and lower exit rates; technical efficiency is unimportant for entry, but matters for exit; a low level of tenure is associated both with higher entry rates and higher exit rates, although only the former effect is significant; the age effect is non-linear in the entry equation but insignificant in the exit model; and wood is associated with a much higher entry rate than the other sectors. Indeed, the log likelihood value of the random effects model is only marginally higher than that in Model [2], suggesting that our regressors and state dependence controls together do a good job in controlling for overall heterogeneity. It is noteworthy that Bigsten et al. [2000] also find unobserved heterogeneity to matter very little in the exporting equation. However, when we estimated the more restrictive version of the model, only allowing for intercept state dependence (i.e. a logit with a lagged dependent variable), we did find significant evidence for unobserved heterogeneity. Not only is this model a mis-specification (given what we now know about the state dependence in the slope parameters), however, but it is also much less informative than Models [2] and [3].

The main conclusions to emerge from this detailed analysis of the determinants of Ghanaian manufacturing exports are that efficiency plays some role in the exit, but not entry, decision, and that exporting firms are relatively capital intensive. There is virtually no exporting of unskilled labour intensive manufactures.

\section{The Micro Evidence on Exports and Labour Intensity}

In the last section two sections we have shown that in Ghana, which has had a relatively long and sustained period of trade reform, the extent of investment or growth in manufacturing exports was extremely small and that exports were concentrated in the capital intensive wood sector. In this section we ask whether the pattern for Ghana is similar in other countries for which we have micro data. How labour intensive are their exports and are they as concentrated by sector as those in Ghana? In order to address this issue in a comparative context we proceed by asking how exporting differs by sector and by firm size and then linking this pattern of exports to the pattern of labour intensity of the technology across sectors.

The picture that emerges from the micro survey evidence for the Cameroon, Ghana, Kenya and Zimbabwe is presented in Figures 1-4. In Figure 1 we show the percentage of firms exporting by sector. The pattern across the four countries is different. In the Cameroon and Ghana there is one dominant export sector, in both countries 70 per cent of firms in wood processing export. In contrast in both Kenya and Zimbabwe exporting is spread across a much wider range of sectors. This is particularly true in Zimbabwe where all sectors have at least 40 per cent of firms exporting. This micro evidence confirms the findings from Wood and Jordan [this issue] that Zimbabwe is a relative successful exporter of manufactures and, unlike Ghana and the Cameroon, its exports are not confined to the processing of primary products.

In Figure 2 the breakdown by firm size is presented. Here there is a uniform pattern across all the countries in that large firms are much more likely to export than smaller ones. Large throughout refers to firms with more than 100 employees. Ghana is shown to be by far the least export oriented of the countries and Figure 2 shows this is due not to the fact that firms in the Ghana sample are smaller but is primarily the result of much lower levels of export orientation than for other countries.

In Figure 3 we show how capital intensive by sector and in figure 4 by firm size. Some common findings emerge across the countries. First, for all four countries, the most capital intensive firms are the largest. Ghana is the only country for which there is not a monotonic relationship between firm size and capital intensity and even for Ghana small and micro firms, those with less than 30 employees, have less than half the capital of larger firms. The second common finding across all the countries is that the most labour intensive sector is garments (figure 3). Finally we note that, with the exception of Zimbabwe, the garments sectors is among the least export oriented (figure 1). 
In summary the data presented in the figures shows that in some important respects Ghana is not typical of other African countries. Manufacturing exports from both Kenya and Zimbabwe are far more diversified by sector than is the case for Ghana. While it is true for all countries that exporting firms tend to be capital intensive as they are large, such firms in Ghana are much less successful in exporting than they are in the other countries. The only country which has been able to have a significant number of firms exporting in garments, the least capital intensive sector, is Zimbabwe. In this context it is Zimbabwe which is atypical rather than Ghana. In the final section we return to the possible reasons for these outcomes.

\section{What determines the performance of firms in Africa's manufacturing sector?}

Some aspects of possible answers to that question are implicit in the other papers in this symposium. Wood and Jordan [this issue] argue that Zimbabwe's relative good performance can be traced to higher skill levels. Milner, Morrissey and Rudaheranwa [this issue] show that non-policy barriers to trade in Uganda are high and can explain the poor response of manufacturing exports to trade liberalisation. In this paper we have argued that different types of skill impact on performance in distinct ways. It has proved useful to distinguish between the observable component, the education and experience of the workforce, and the technical efficiency of the firms. While the two may be related they are distinct and, for Ghana, we have evidence that the latter dimension of skills is important for both investment and exporting. Comparative data shows that firms in all the countries we have compared have very similar amounts of human capital, Bigsten et al. [forthcoming]. So it is likely that in explaining differences across countries it is the unobservable components of skills which are likely to be most important. The poor performance of manufacturing in most African countries is arguably due to its inability to export its products. The lack of such exports must reflect either high unskilled labour costs in Africa, or relatively high transactions costs, or high wages relative to productivity, or some combination of all these elements.

The first of these explanations implies that it is untrue that unskilled labour is cheap. The logic of this argument is that natural resources raise the price of unskilled labour and that an analysis based on ratios of skilled and unskilled labour is misleading given the importance of natural resources in impacting on the price of unskilled labour. The capital intensity of exports would reflect in part the complementarity of capital and natural resources in processing natural resources (this would explain the capital intensity in Ghana given the concentration on the wood sector). It needs however to be noted that any argument that the supply price for unskilled labour is high is hard to reconcile with the evidence that, at least for Ghana, wages are lower than in Chinese enterprises and that unskilled wages have fallen substantially over the 1990s, Teal [2000a].

The second explanation is in terms of high transaction costs. It has been argued by Collier [2000] that as manufactures are intensive is such costs any reduction in them will benefit manufacturing exports. If policy has been a major cause of high transactions costs, then high return investments will not be available in the manufacturing sector. Until transaction costs are reduced manufacturing production will remain concentrated on supplying the domestic market (the factors that impose high costs of exports also act to protect the domestic market) and export growth will continue to be concentrated in natural resources. The evidence from Ghana, Uganda and Zimbabwe could be argued to provide support for this view.

The third explanation is that there are important distortions in factors markets within African economies that prevent the factor prices firms face reflecting the opportunity cost of the factors. In this view the lack of unskilled labour intensive exports is not the result of unskilled wages being too high but that firms in the export market, which effectively means firms which employ more than 100 workers, paying wages substantially above the supply price of labour. In a comparison of Ghana and Mauritius Teal [1999] argued that firms in Mauritius were four times more efficient than those in Ghana while wages, for larger firms, were only three times higher. Wages in large firms greatly exceed those in smaller ones, for Africa, Bigsten el al [forthcoming], so a mismatch between wage costs and productivity could be one element explaining poor export growth. 
The explanation for the poor performance of manufacturing exports from Africa does not have to be the same for all countries or the same for all sectors within manufacturing. The poor performance is however almost certainly a large part of the explanation for the low levels of investment in the sector. The micro data on investment in manufacturing show no evidence of any recovery in the $1990 \mathrm{~s}$. A flexible accelerator specification of the investment function has been shown to work across a range of African countries and such a specification implies that investment will respond to demand growth. Low investment is caused by low demand growth, an important part of which is the lack of growth for exports. If this is correct then the factors which constrain manufacturing exports directly account for the low levels of investment.

Numerous other factors have been argued to be responsible for low investment in Africa. These include the high levels of uncertainty faced by entrepreneurs and the relatively high cost of irreversibility to investment in Africa. There is evidence that both these factors matter. Indeed in the case of Ghana, the country on which most of this paper has focused, the extent of uncertainty induced by the substantial changes in the real exchange rate in the 1990s will have been of particular importance for those considering entering the export market. It is though possible to argue that a primary focus on these explanations is misplaced. Such factors as uncertainty will primarily limit the access of firms to external finance. There is a common finding across all the studies of manufacturing investment in Africa that own finance, while a significant determinant of investment, has only a small effect. If firms wished to invest more they could, the problem is to explain why they do not wish to. Similarly it is hard to argue that irreversibility is important in the garment sector. The capital equipment in the sector, in many instances, is second hand sewing machines. There is a well functioning market for such assets. It is possible that the factors limiting investment go deeper than uncertainty and irreversibility and reflect the underlying lack of profitability for labour intensive manufacturing exports.

Finally, we consider the question posed in the introduction as to whether this limited growth for manufacturing investment and exports does limit the long run growth of African economies. The answer to that question depends on which of the reasons for the low exports is correct. If it is the high costs of non-policy barriers to trade (the example in this symposium is Uganda) then the answer is no. Similarly if unskilled labour costs are high due to the high natural resource endowment of the economies then again the answer is no. In contrast if the prices firms pay exceed the opportunity costs of labour then the potential for a successful and profitable export sector exists, and its lack may be a crucial part of the explanation for the failure of African economies generally, and the Ghana economy in particular, to emulate the NICs. 


\section{References}

Abel, A. and J. Eberly (1994) "A unified model of investment under uncertainty", The American Economic Review, Vol. 84, No. 5, December, pp.1369-1384.

Alderman, H. (1991) Downturn and Economic Recovery in Ghana: Impacts on the poor, Cornell Food and Nutrition Program, Monograph 10.

Arellano, M. and R. Carrasco (1999). "Binary Choice Panel Data Models with Predetermined Variables." Mimeo, CEMFI.

Bernard, A. B. and J. B. Jensen (1999) "Exporting and Productivity”, Yale School of Management and Carnegie Mellon University, mimeo.

Bigsten, A., P. Collier, S. Dercon, M. Fafchamps, B.Gauthier, J.W. Gunning, J. Habarurema, A. Isaksson, A. Oduro, R. Oostendorp, C. Pattillo, M. Söderbom, F.Teal, A. Zeufack "Exports of African Manufactures: Macro Policy and Firm Behaviour", (1999a), Journal of International Trade and Development, 8, 1, 53-71.

Bigsten, A., P. Collier, S. Dercon, B. Gauthier, J. W. Gunning, A. Isaksson, A. Oduro, R. Oostendorp, C. Pattillo, M. Söderbom , M. Sylvain, F. Teal, A. Zeufack "Investment in Africa's Manufacturing Sector: a Four Country Panel Data Analysis" (1999b) Oxford Bulletin of Economics and Statistics, Vol. 61, No. 4, November, pp.489-512.

Bigsten, A., P. Collier, S. Dercon, M. Fafchamps, B. Gauthier, J. W. Gunning, A. Isaksson, A. Oduro, R. Oostendorp, C. Pattillo, M. Söderbom, F. Teal, A.Zeufack "Exports and Firm-level efficiency in African Manufacturing, (2000), CSAE mimeo.

Bigsten, A., P. Collier, S. Dercon, M. Fafchamps, B. Gauthier, J. W. Gunning, A. Isaksson, A. Oduro, R. Oostendorp, C. Pattillo, M. Söderbom, F. Teal, A. Zeufack and S. Appleton "Rates of Return on Physical and Human Capital in Africa's Manufacturing Sector", Economic Development and Cultural Change, forthcoming.

Clerides S., S. Lach, and J. Tybout (1998), "Is Learning by Exporting Important? Micro-Dynamic Evidence From Colombia, Mexico and Morocco", Quarterly Journal of Economics, August, 903-948.

Collier, P. (2000) “Africa's comparative advantage”, chapter 2 in H. Jalilian, M.Tribe and J. Weiss (eds.) Industrial Development and Policy in Africa, Edward Elgar, Cheltenham, UK.

Grossman, G. and E. Helpman. (1991) Innovation and growth in the Global Economy, Cambridge, Mass: MIT Press.

Krugman P. (1984) "Import Protection as Export Promotion : Internal Competition in the presence of oligopolies and economies of scale" In Kierkowski H. ed., Monopolistic Competition and International trade, Oxford University Press.

Krugman, P. (1987) "The Narrow Moving Bank, the Dutch Disease and the competitive Consequences of Mrs Thatcher: Notes on trade in the presence of Dynamic Scale Economies." Journal of Development Economics 27: 41-55.

Moon, C. and J. G. Stotsky (1993). "The Effect of Rent Control on Housing Quality Change: A Longitudinal Analysis," Journal of Political Economy 101, pp. 1114-1148.

Mroz, T. (1999). "Discrete Factor Approximations in Simultaneous Equation Models: Estimating the Impact of a Dummy Endogenous Variable on a Continuous Outcome," Journal of Econometrics 92, pp. 233-274. 
Owens, T. and A. Wood (1997) 'Export Oriented Industrialisation through Primary Processing?', World Development, 25 (9), September, 1453-1470.

Pattillo, C. (1998) "Investment, uncertainty and irreversibility in Ghana", IMF Staff Papers 45, pp.522553.

Roberts, M. and J. Tybout (1997), "The Decision to Export in Colombia: An Empirical Model of Entry with Sunk Costs", American Economic Review, 87(4): 545-64.

Söderbom, M. (2000) "Does Human Capital Drive Physical-Capital Investment? Evidence from Kenya", Mimeo, Department of Economics at Göteborg University.

Teal, F. (1999a) "Why can Mauritius export manufactures and Ghana not?", The World Economy, Vol. 22, No.7, September, pp.981-993.

Teal, F. (1999b) "The Ghanaian Manufacturing Sector 1991-1995: Firm Growth, Productivity and Convergence", The Journal of Development Studies, Vol. 36, No. 1, October, pp.109-127..

Teal, F. (2000a) "Real Wages and the Demand for Skilled and Unskilled Male Labour in Ghana's Manufacturing Sector: 1991-1995", Journal of Development Economics, Vol. 61, pp.447-461.

Teal, F. (2000b) "Micro Foundations of Technological diffusion: An African Data Set", CSAE mimeo, February 2000.

Tybout, J. R. and M. Westbrook (1995) "Trade liberalization and the dimensions of efficiency change in Mexican manufacturing industries", Journal of International Economics, 37, pp.53-78.

Wood, A. (1994) North-South Trade, Employment and Inequality: Changing fortunes in a skill-driven world, Clarendon Press, Oxford.

Wood, A. and K. Berge (1997) "Exporting Manufactures: Human Resources, Natural Resources, and Trade Policy", Journal of Development Studies, 34 (1), 35-59.

Wood, A. and J. Mayer (1998) Africa's Export Structure in a Comparative Perspective, Study No. 4, African Development in a Comparative perspective, UNCTAD, Geneva. 
Figure 1 Percentage of Firms Exporting by Sector
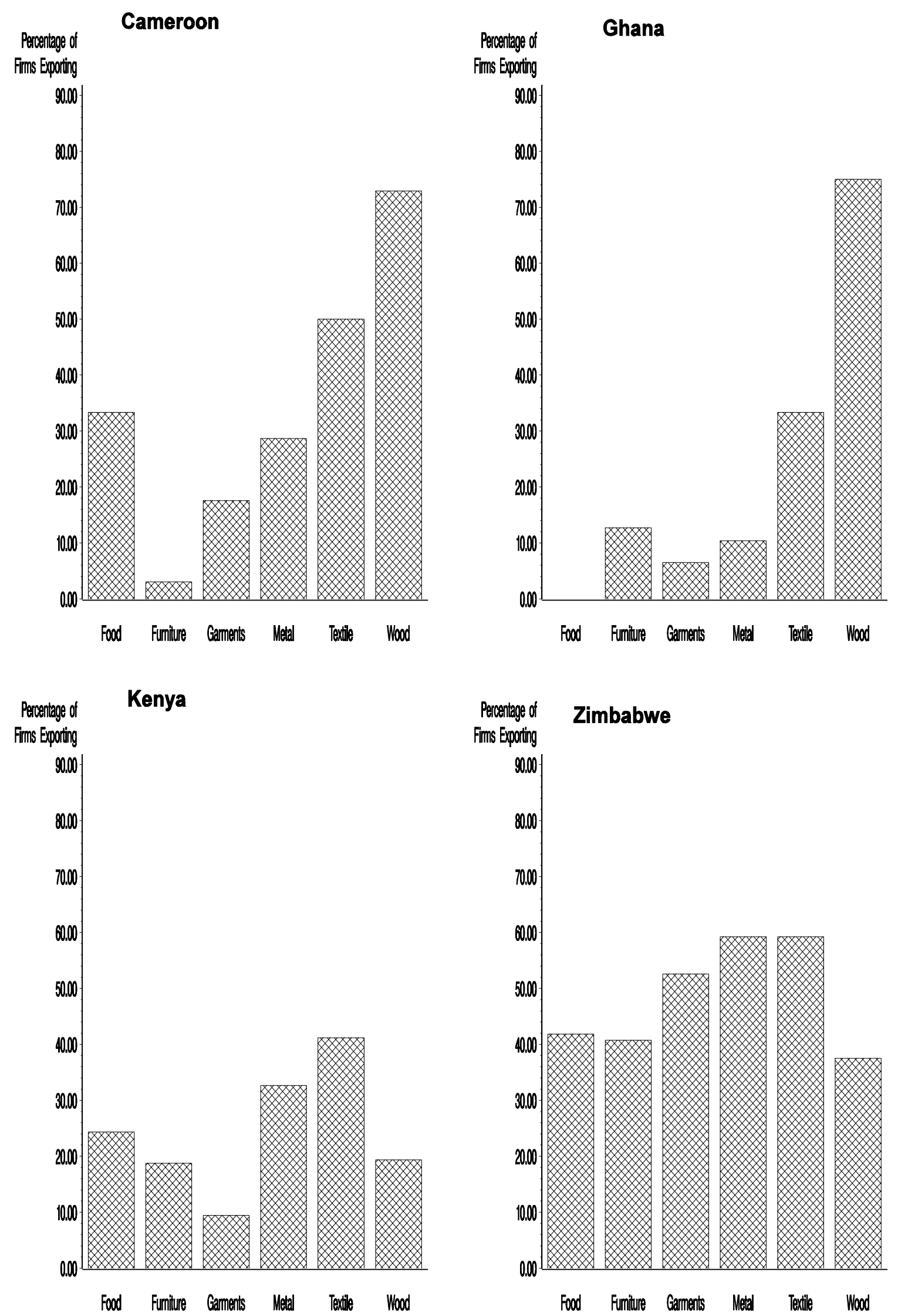
Figure 2 Percentages of Firms Exporting by Firm Size
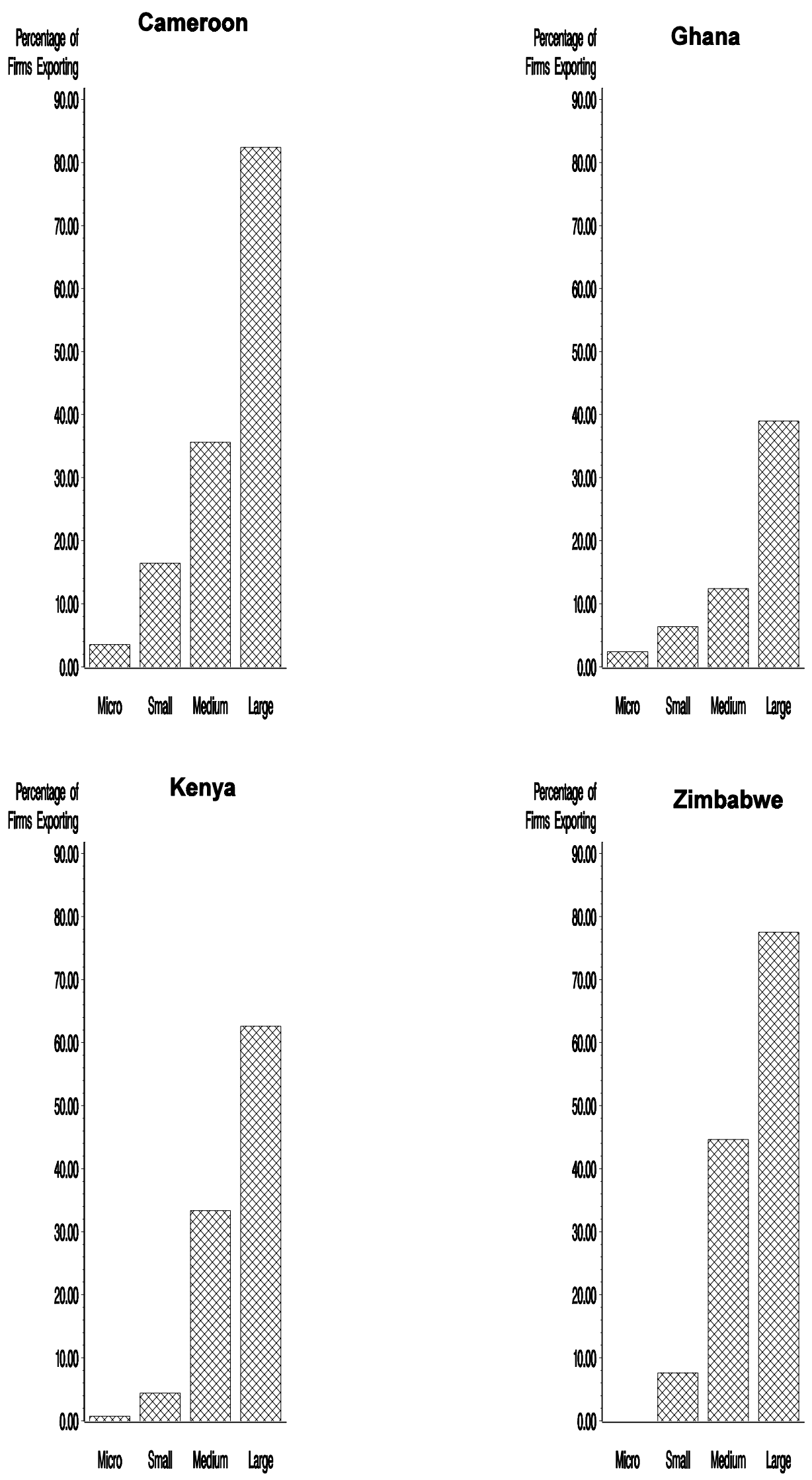
Figure 3 Capital per employee (in US\$ PPP) by Sector
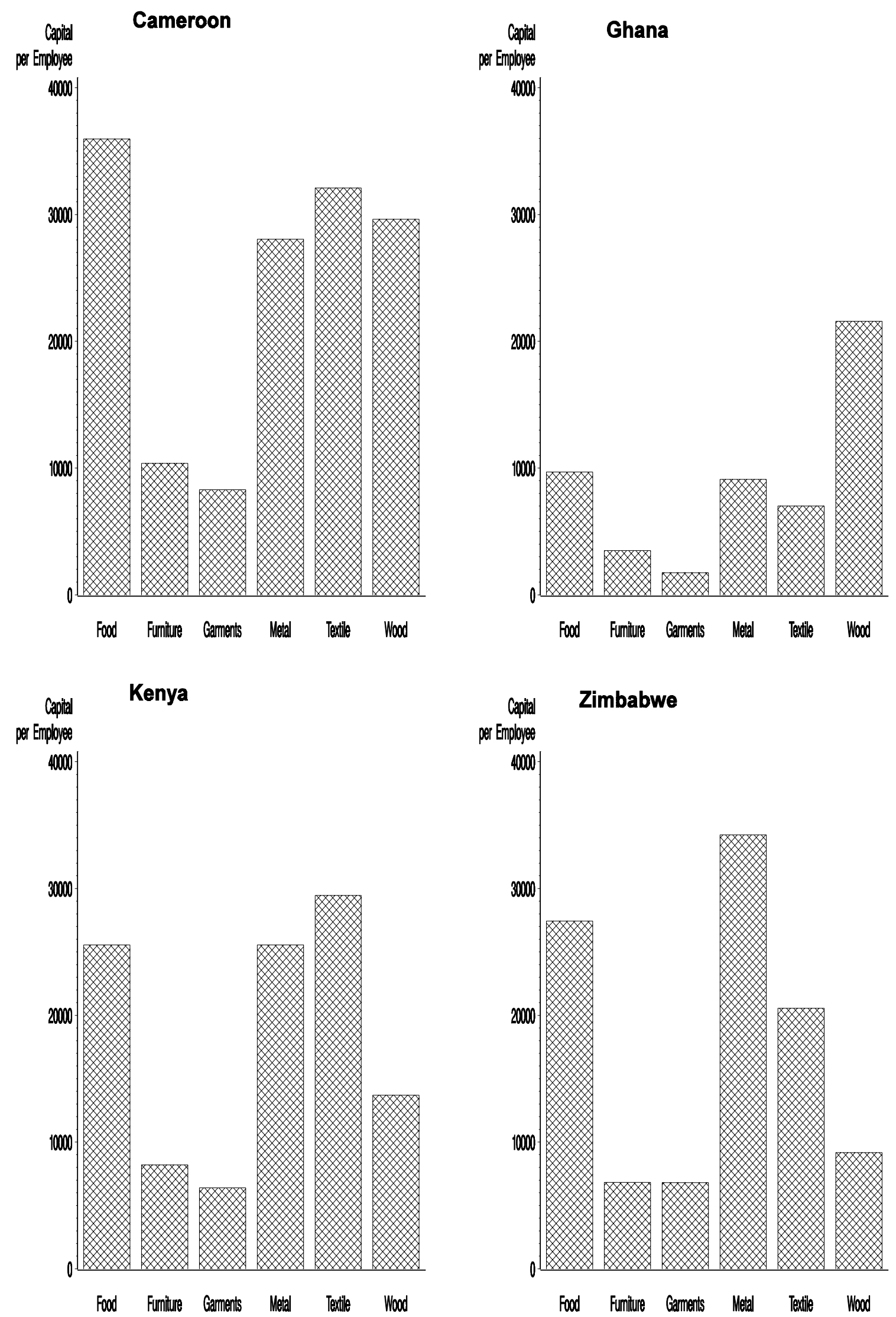
Figure 4 Capital per Employee (in US\$ PPP) by Firm Size
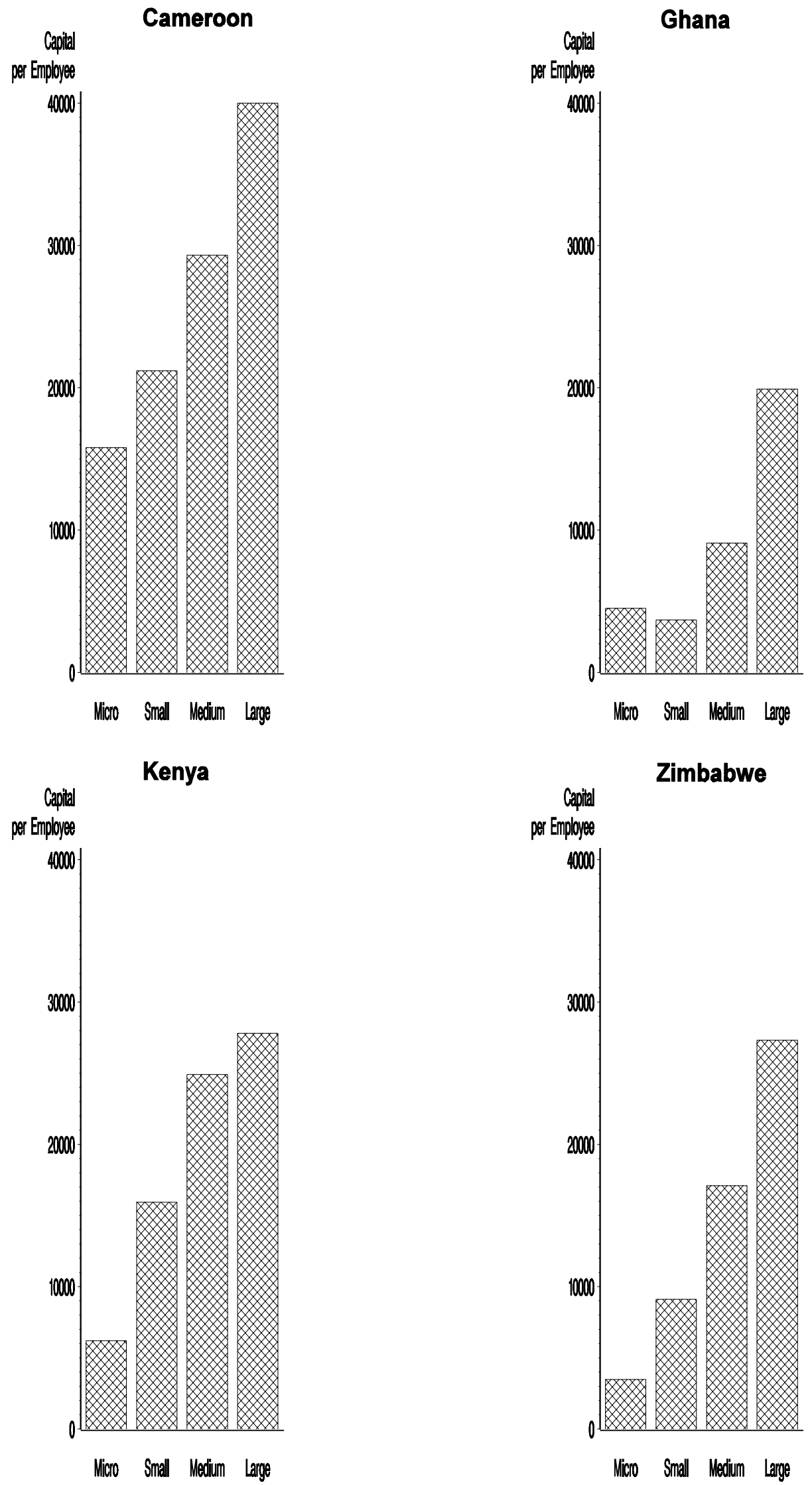


\begin{tabular}{|c|c|c|c|c|c|c|}
\hline & $\mathrm{N}$ & $\begin{array}{l}\text { Proportion } \\
\text { of firms } \\
\text { investing }\end{array}$ & $\begin{array}{l}\text { Investment/ } \\
\text { Value-added } \\
\text { if firm invests }\end{array}$ & $\begin{array}{l}\text { Investment/ } \text { Capital }_{(\mathrm{t}-1)} \\
\text { if firm invests }\end{array}$ & $\begin{array}{l}\text { Investment/ } \\
\text { Value-added }\end{array}$ & $\begin{array}{l}\text { Investment/ } \\
\text { Capital }_{(\mathrm{t}-1)}\end{array}$ \\
\hline \multicolumn{7}{|l|}{ Year } \\
\hline 1993 & 104 & 0.52 & 0.15 & 0.16 & 0.08 & 0.08 \\
\hline 1994 & 96 & 0.46 & 0.09 & 0.11 & 0.04 & 0.05 \\
\hline 1995 & 109 & 0.53 & 0.15 & 0.12 & 0.08 & 0.07 \\
\hline 1996 & 106 & 0.47 & 0.31 & 0.15 & 0.15 & 0.07 \\
\hline 1997 & 123 & 0.33 & 0.16 & 0.07 & 0.05 & 0.02 \\
\hline \multicolumn{7}{|l|}{ Sector } \\
\hline Food & 99 & 0.46 & 0.21 & 0.12 & 0.10 & 0.05 \\
\hline Furniture & 128 & 0.50 & 0.14 & 0.16 & 0.07 & 0.08 \\
\hline Metal & 149 & 0.49 & 0.16 & 0.10 & 0.08 & 0.05 \\
\hline Textile & 11 & 0.45 & 0.11 & 0.03 & 0.05 & 0.02 \\
\hline Garments & 111 & 0.30 & 0.14 & 0.15 & 0.04 & 0.05 \\
\hline Wood & 40 & 0.63 & 0.28 & 0.12 & 0.18 & 0.07 \\
\hline \multicolumn{7}{|c|}{ Size (large: $>100$ employees, medium: $>30$ and $<100$, small: $>5$ and $<30$, micro: $<6$ ) } \\
\hline Large & 90 & 0.73 & 0.24 & 0.09 & 0.17 & 0.07 \\
\hline Medium & 156 & 0.48 & 0.19 & 0.15 & 0.09 & 0.07 \\
\hline Small & 227 & 0.37 & 0.12 & 0.13 & 0.05 & 0.05 \\
\hline Micro & 65 & 0.31 & 0.10 & 0.10 & 0.03 & 0.03 \\
\hline \multicolumn{7}{|l|}{ Export Status } \\
\hline Exporter & 91 & 0.62 & 0.25 & 0.12 & 0.16 & 0.07 \\
\hline Non-exporter & 447 & 0.43 & 0.15 & 0.13 & 0.06 & 0.05 \\
\hline All Firms & 538 & 0.46 & 0.17 & 0.12 & 0.08 & 0.06 \\
\hline
\end{tabular}




\begin{tabular}{|c|c|c|c|c|}
\hline \multicolumn{5}{|c|}{$\begin{array}{l}\text { Table } 2 \text { Measuring Efficiency from the Production F } \\
\text { Dependent Variable: Ln (Real Value-added/Employee) }\end{array}$} \\
\hline & \multicolumn{2}{|l|}{ [1] } & \multicolumn{2}{|l|}{$[2]$} \\
\hline Constant & 9.09 & {$[23.4]^{* *}$} & 9.02 & {$[25.7]^{* *}$} \\
\hline Ln (Capital/Employee) & 0.20 & {$[8.1]^{* *}$} & 0.21 & {$[9.5]^{* *}$} \\
\hline Ln (Education/ Employee) & 0.34 & {$[2.4]^{*}$} & 0.31 & {$[2.4]^{*}$} \\
\hline Ln (Tenure/Employee) & 0.18 & {$[3.1]^{* *}$} & 0.19 & {$[3.7]^{* *}$} \\
\hline Food & 0.19 & {$[1.7]^{+}$} & 0.29 & {$[2.9]^{* *}$} \\
\hline Textile & -0.13 & {$[0.6]$} & -0.14 & {$[0.6]$} \\
\hline Garment & -0.89 & {$[7.0]^{* *}$} & -0.87 & {$[7.7]^{* *}$} \\
\hline Furniture & -0.61 & {$[5.4]^{* *}$} & -0.55 & {$[5.4]^{* *}$} \\
\hline Wood & -0.47 & {$[2.5]^{*}$} & -0.21 & {$[1.4]$} \\
\hline Export & 0.24 & {$[1.8]^{+}$} & & \\
\hline Any Foreign Ownership & 0.28 & {$[2.6]^{*}$} & 0.27 & {$[2.7]^{* *}$} \\
\hline Firm Age & 0.02 & {$[1.8]^{+}$} & 0.02 & {$[2.3]^{*}$} \\
\hline Firm Age $^{2}$ & -0.0002 & {$[1.5]$} & -0.0003 & {$[1.9]^{+}$} \\
\hline Round 2 & 0.02 & {$[0.2]$} & -0.003 & {$[0.03]$} \\
\hline Round 3 & -0.02 & {$[0.1]$} & -0.01 & {$[0.1]$} \\
\hline Round 4 (a) & & & 0.37 & {$[2.9]^{* *}$} \\
\hline Round 5 & 0.17 & {$[1.3]$} & 0.17 & {$[1.3]$} \\
\hline Round 6 & -0.22 & {$[1.6]$} & -0.22 & [1.7] \\
\hline Round 7 & -0.23 & [1.7] & -0.22 & {$[1.7]$} \\
\hline $\mathrm{N}$ & 921 & & 1095 & \\
\hline White $\chi^{2}[\mathrm{df}]$ & 164 & {$[170]$} & 168 & [165] \\
\hline Adjusted $\mathrm{R}^{2}$ & 0.39 & & 0.39 & \\
\hline $\begin{array}{l}\mathrm{N} \text { is the number of observa } \\
* * \text { is significant at } 1 \text { per ce } \\
\text { (a) Due to an error in the de } \\
\text { so we have omitted this yea }\end{array}$ & $\begin{array}{l}\text { tatistics in } \\
\text { gnificant } \\
\text { the questi } \\
\text { regressio }\end{array}$ & $\begin{array}{l}\text { [ ] parent } \\
\text { at } 5 \text { per ce } \\
\text { onnaire dat } \\
\text { n including }\end{array}$ & $\begin{array}{l}\text { at } 10 \text { per } \\
\text { d for exp }\end{array}$ & $\begin{array}{l}\text { cent. } \\
\text { orting for the fourth year }\end{array}$ \\
\hline
\end{tabular}




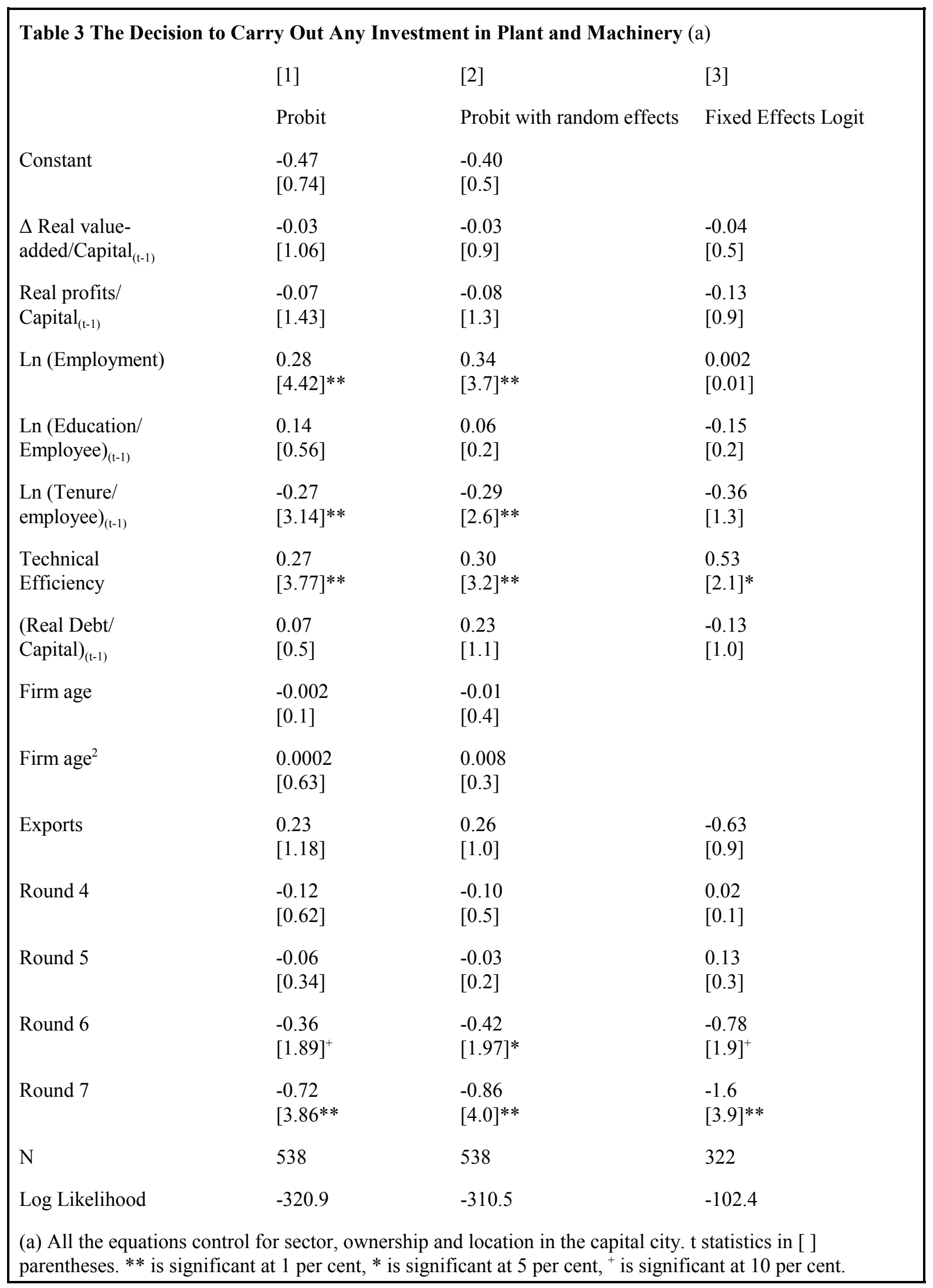


Table 4 Investment in Plant and Machinery (a) Investment/Capital ${ }_{(\mathrm{t}-1)}$ if firm invest

Constant

Lagged [Investment/

Capital $\left._{(\mathrm{t}-1)}\right]$

$\Delta$ Real value-added/

Capital $_{(\mathrm{t}-1)}$

Real profits/

Capital $_{(\mathrm{t}-1)}$

Ln (Employment)

Ln (Education/

Employee) $)_{(\mathrm{t}-1)}$

Ln (Tenure/

employee) $)_{(t-1)}$

Technical

Efficiency

(Real Debt/

Capital $_{(\mathrm{t}-1)}$

Firm age

Firm age $^{2}$

Exports

Round 4

Round 5

Round 6

Round 7

Lambda/Fixed Effects

$\mathrm{N}$

Adjusted $\mathrm{R}^{2}$
[1]

[2]

$-0.08$

[0.3]

0.16

0.14

[2.4]*

0.01

[1.3]

0.06

$[6.3]^{* *}$

0.01

[1.1]

0.04

[0.7]

$-0.03$

$[1.86]^{+}$

$-0.03$

$[1.66]^{+}$

0.12

[5.6]**

0.004

[1.2]

$-0.0001$

[1.0]

0.02

[0.5]

$-0.06$

[1.6]

$-0.05$

[1.3]

0.02

[0.5]

$-0.06$

[1.6]

246

0.29

0.01

[0.8]

0.05

$[4.7]^{*}$

0.004

[0.9]

[0.6]

0.03

[0.6]

$-0.06$

[1.0]

$-0.04$

[0.7]

0.01

[0.2]

$-0.08$

[1.2]

246
$[1.83]^{+}$

0.01

[1.3]

$[3.5]^{* *}$

0.08

[3.9]**

$-0.06$

[0.91]

0.02

[0.2]

$-0.08$

[2.2]*

$-0.05$

$[1.7]^{+}$

0.03

[0.5]

$-0.0001$

0.03

[0.6]

$-0.04$

[0.8]

$-0.04$

[1.0]

0.05

[1.0]

$-0.04$

[0.9]

$0.04[0.4]$

Fixed effects

246

0.26

(a) All the equations control for sector, ownership and location in the capital city. $t$ statistics in [ ] parentheses. ${ }^{* *}$ is significant at 1 per cent, $*$ is significant at 5 per cent, ${ }^{+}$is significant at 10 per cent. 


\begin{tabular}{|c|c|c|c|c|c|}
\hline \multicolumn{6}{|c|}{ Table 5 Exports to all destinations } \\
\hline & $\mathrm{N}$ & Employment & $\begin{array}{l}\text { Proportion of } \\
\text { Firms Exporting }\end{array}$ & $\begin{array}{l}\text { Percentage } \\
\text { Exported if firm } \\
\text { exports }\end{array}$ & $\begin{array}{l}\text { Percentage } \\
\text { Exported }\end{array}$ \\
\hline \multicolumn{6}{|l|}{ Year } \\
\hline 1992 & 114 & 46 & 0.09 & 40.7 & 3.0 \\
\hline 1993 & 117 & 50 & 0.15 & 47.6 & 6.8 \\
\hline 1995 & 131 & 60 & 0.11 & 56.8 & 2.8 \\
\hline 1996 & 127 & 80 & 0.21 & 56 & 12.4 \\
\hline 1997 & 138 & 110 & 0.22 & 49.3 & 10.8 \\
\hline \multicolumn{6}{|l|}{ Sector } \\
\hline Chemical & 4 & 99 & 0.25 & 8.8 & 0.5 \\
\hline Food & 126 & 64 & 0.11 & 32.3 & 2.4 \\
\hline Furniture & 141 & 59 & 0.11 & 43.9 & 4.5 \\
\hline Metal & 165 & 65 & 0.11 & 20.7 & 1.8 \\
\hline Textile & 17 & 268 & 0.24 & 56.2 & 9.8 \\
\hline Garments & 124 & 19 & 0.05 & 48.7 & 2.3 \\
\hline Wood & 50 & 195 & 0.82 & 74.8 & 59.1 \\
\hline \multicolumn{6}{|c|}{ Size (large: $>100$ employees, medium: $>30$ and $<100$, small: $>5$ and $<30$, micro: $<6$ ) } \\
\hline Large & 110 & 283 & 0.52 & 56 & 25.2 \\
\hline Medium & 175 & 50 & 0.10 & 50.3 & 5.8 \\
\hline Small & 268 & 15 & 0.09 & 41.1 & 3.3 \\
\hline Micro & 74 & 4 & 0 & 30.3 & 0 \\
\hline All Firms & 627 & 71 & 0.16 & 50.5 & 7.4 \\
\hline
\end{tabular}




\begin{tabular}{lllll}
\multicolumn{7}{l}{ Table 6 Entry and Exit } & & \\
\multicolumn{7}{|c}{ Proportion entering given not exporting } & \multicolumn{2}{l}{ Proportion exiting given exporting } \\
Large & 0.21 & {$[57]$} & 0.15 & {$[53]$} \\
Medium & 0.02 & {$[154]$} & 0.29 & {$[21]$} \\
Small & 0.03 & {$[247]$} & 0.02 & {$[21]$} \\
Micro & 0 & {$[73]$} & 1 & {$[1]$} \\
All firms & 0.04 & {$[531]$} & 0.21 & {$[96]$} \\
The figures in [ ] parentheses are the number of observations. & &
\end{tabular}




\begin{tabular}{|c|c|c|c|c|c|}
\hline \multicolumn{6}{|c|}{ Table 7. Parameter Estimates from Logistic Exporting Models ${ }^{(a)}$} \\
\hline & \multirow{2}{*}{$\begin{array}{l}\text { Model [1] } \\
\text { Exporting }\end{array}$} & \multicolumn{2}{|c|}{ Model [2] } & \multicolumn{2}{|c|}{ Model [3] } \\
\hline & & Entry & Exit & Entry & Exit \\
\hline Ln (Employment) ${ }_{(t-1)}$ & $\begin{array}{l}0.53 \\
{[3.55]^{* *}}\end{array}$ & $\begin{array}{l}0.46 \\
{[2.17]^{*}}\end{array}$ & $\begin{array}{l}-0.46 \\
--\end{array}$ & $\begin{array}{c}0.52 \\
{[2.22]^{*}}\end{array}$ & $\begin{array}{l}-0.52 \\
--\end{array}$ \\
\hline Technical Efficiency $(t-1)$ & $\begin{array}{c}0.29 \\
{[1.81]^{+}}\end{array}$ & $\begin{array}{c}0.06 \\
{[0.25]}\end{array}$ & $\begin{array}{l}-1.36 \\
{[2.56]^{*}}\end{array}$ & $\begin{array}{c}0.02 \\
{[0.10]}\end{array}$ & $\begin{array}{l}-1.32 \\
{[2.07]^{*}}\end{array}$ \\
\hline$\Delta$ Technical Efficiency $_{(\mathrm{t})}$ & $\begin{array}{c}0.10 \\
{[0.52]}\end{array}$ & $\begin{array}{c}0.35 \\
{[1.00]}\end{array}$ & $\begin{array}{c}0.75 \\
{[1.28]}\end{array}$ & $\begin{array}{c}0.32 \\
{[0.88]}\end{array}$ & $\begin{array}{c}0.77 \\
{[1.10]}\end{array}$ \\
\hline $\operatorname{Ln}(\text { Capital/Employee })_{(t-1)}$ & $\begin{array}{l}0.52 \\
{[4.45]^{* *}}\end{array}$ & $\begin{array}{l}0.44 \\
{[2.78]^{* *}}\end{array}$ & $\begin{array}{l}-0.44 \\
--\end{array}$ & $\begin{array}{c}0.41 \\
{[2.45]^{*}}\end{array}$ & $\begin{array}{l}-0.41 \\
--\end{array}$ \\
\hline Ln (Tenure) & $\begin{array}{l}-0.05 \\
{[0.19]}\end{array}$ & $\begin{array}{l}-0.75 \\
{[2.07]^{*}}\end{array}$ & $\begin{array}{l}-0.77 \\
{[1.09]}\end{array}$ & $\begin{array}{l}-0.82 \\
{[2.18]^{*}}\end{array}$ & $\begin{array}{l}-0.66 \\
{[0.76]}\end{array}$ \\
\hline Ln (Education) & $\begin{array}{c}0.59 \\
{[0.74]}\end{array}$ & $\begin{array}{c}0.67 \\
{[0.54]}\end{array}$ & $\begin{array}{l}-0.67 \\
--\end{array}$ & $\begin{array}{c}1.30 \\
{[0.92]}\end{array}$ & $\begin{array}{l}-1.30 \\
--\end{array}$ \\
\hline Round 3 & $\begin{array}{l}1.06 \\
{[1.85]^{* *}}\end{array}$ & $\begin{array}{l}2.67 \\
{[2.63]^{* *}}\end{array}$ & $\begin{array}{l}-2.67 \\
--\end{array}$ & $\begin{array}{c}2.50 \\
{[2.46]^{*}}\end{array}$ & $\begin{array}{l}-2.50 \\
--\end{array}$ \\
\hline Round 5 & $\begin{array}{c}0.57 \\
{[0.98]}\end{array}$ & $\begin{array}{l}2.13 \\
{[1.97]^{*}}\end{array}$ & $\begin{array}{c}0.68 \\
{[0.65]}\end{array}$ & $\begin{array}{c}1.87 \\
{[1.69]^{+}}\end{array}$ & $\begin{array}{c}1.50 \\
{[1.14]}\end{array}$ \\
\hline Round 6 & $\begin{array}{c}0.85 \\
{[1.53]}\end{array}$ & $\begin{array}{c}1.59 \\
{[1.40]}\end{array}$ & $\begin{array}{c}0.31 \\
{[0.31]}\end{array}$ & $\begin{array}{c}1.36 \\
{[1.18]}\end{array}$ & $\begin{array}{c}1.07 \\
{[0.79]}\end{array}$ \\
\hline Round 7 & $\begin{array}{c}0.98 \\
{[1.79]^{+}}\end{array}$ & $\begin{array}{c}1.68 \\
{[1.79]^{+}}\end{array}$ & $\begin{array}{l}-1.68 \\
--\end{array}$ & $\begin{array}{c}1.33 \\
{[1.30]}\end{array}$ & $\begin{array}{l}-1.33 \\
--\end{array}$ \\
\hline Firm age & $\begin{array}{c}0.09 \\
{[1.87]^{+}}\end{array}$ & $\begin{array}{c}0.35 \\
{[2.90]^{* *}}\end{array}$ & $\begin{array}{c}0.07 \\
{[0.58]}\end{array}$ & $\begin{array}{c}0.39 \\
{[3.16]^{* *}}\end{array}$ & $\begin{array}{c}0.08 \\
{[0.57]}\end{array}$ \\
\hline Firm age $^{2} / 100$ & $\begin{array}{l}-0.26 \\
{[2.87]^{* *}}\end{array}$ & $\begin{array}{l}-0.66 \\
{[2.63]^{* *}}\end{array}$ & $\begin{array}{c}0.06 \\
{[0.20]}\end{array}$ & $\begin{array}{l}-0.75 \\
{[2.98]^{* *}}\end{array}$ & $\begin{array}{c}0.01 \\
{[0.04]}\end{array}$ \\
\hline Food & $\begin{array}{c}0.04 \\
{[0.09]}\end{array}$ & $\begin{array}{c}0.41 \\
{[0.62]}\end{array}$ & $\begin{array}{l}-0.41 \\
--\end{array}$ & $\begin{array}{c}0.36 \\
{[0.54]}\end{array}$ & $\begin{array}{l}-0.36 \\
--\end{array}$ \\
\hline Textiles & $\begin{array}{l}-0.17 \\
{[0.24]}\end{array}$ & $\begin{array}{c}0.81 \\
{[0.94]}\end{array}$ & $\begin{array}{l}-0.81 \\
--\end{array}$ & $\begin{array}{c}0.88 \\
{[1.01]}\end{array}$ & $\begin{array}{l}-0.88 \\
--\end{array}$ \\
\hline Garment & $\begin{array}{c}0.71 \\
{[1.22]}\end{array}$ & $\begin{array}{c}0.54 \\
{[0.68]}\end{array}$ & $\begin{array}{l}-0.54 \\
--\end{array}$ & $\begin{array}{c}0.06 \\
{[0.06]}\end{array}$ & $\begin{array}{l}-0.06 \\
--\end{array}$ \\
\hline Wood & $\begin{array}{l}4.56 \\
{[6.51]^{* *}}\end{array}$ & $\begin{array}{c}5.94 \\
{[4.24]^{* *}}\end{array}$ & $\begin{array}{l}-0.05 \\
{[0.03]}\end{array}$ & $\begin{array}{c}5.76 \\
{[4.07]^{* *}}\end{array}$ & $\begin{array}{c}0.16 \\
{[0.09]}\end{array}$ \\
\hline Furniture & $\begin{array}{c}0.63 \\
{[1.40]}\end{array}$ & $\begin{array}{c}0.32 \\
{[0.51]}\end{array}$ & $\begin{array}{l}-0.32 \\
--\end{array}$ & $\begin{array}{c}0.01 \\
{[0.01]}\end{array}$ & $\begin{array}{l}-0.01 \\
--\end{array}$ \\
\hline $\begin{array}{l}-\left[\text { Constant }_{\text {(exit) }}\right. \\
\left.+ \text { Constant }_{(\text {entry) }}\right]\end{array}$ & $\begin{array}{c}0.00 \\
\text { (assumed) }\end{array}$ & & & & \\
\hline State dependence & No & & & & \\
\hline Firm random effects & No & & & & \\
\hline NT $(\mathrm{N})$ & $627(207)$ & 627 & & 627 & \\
\hline Log likelihood & -244.9 & & & & \\
\hline
\end{tabular}

(a) All equations control for ownership and location in the capital city. Asymptotic $z$ statistics in [ ] parentheses. ** is significant at 1 per cent, $*$ is significant at 5 per cent, ${ }^{+}$is significant at 10 per cent. 
Data Appendix ${ }^{10}$

The data is drawn from surveys of Ghana's manufacturing sector which have been conducted over the period 1992 to 1998. Annual data is available covering the period 1991 to 1997 . The data for 1991 to 1993 were collected in an annual survey which was part of the RPED (Regional Program on Enterprise Development) organised by the World Bank. The data for 1994 and 1995 were collected in a single survey conducted in 1996. Similarly the data for 1996 and 1997 were collected in a survey carried out in 1998. All the surveys involved the collection of both firm level information and detailed information on a sample of workers in the firm. Workers were asked for information on their education and the time spent working in the firm.

Real Value-added.

The real value-added data is obtained from nominal value-added defined as:

Nominal Value-added = Output - Raw material Inputs - Indirect costs

To obtain real value-added the components of the nominal series are deflated. Output is deflated by a firm-specific price index for output, raw material inputs are deflated by a price index for raw material costs while indirect costs are deflated by using the consumer price index.

Real Physical Capital Stock.

This series is obtained by summing the investment data, where the base used is the data reported for the replacement value of the capital stock in a base year.

\section{Human Capital}

The two observable components of the human capital of the firms, which are used in the regressions, are the education and experience of the workforce. To obtain these measures of the human capital stock available to the firm the worker data was merged with that from the firm. In aggregating from the worker to the firm level it was necessary to use weights to ensure that we can move from individual data to firm based averages. We weighted the human capital variables by the proportion of workers in a given occupational class within the firm. Eight common occupational groups across the rounds of the survey were identified. The most important occupational groups in the sample are production and support workers (which are one category) and the apprentices. These occupational categories for the worker level data were matched with the occupational categories given in the firm level data. With the matching by occupations human capital variables, which are weighted averages of the firms' workers characteristics, can be created. The education and tenure variables used in the regressions are these weighted averages.

\section{Real Borrowing}

The debt of the firm consists of borrowing from banks, non-bank financial institutions, government programmes and foreign banks; overdrafts are not included. The debt is deflated by the firm-specific price index for outputs.

Real profits

Nominal Profits, defined as value-added less wages, are deflated by the firm-specific price for outputs.

Employment

Refers to the total number of full time employees whether classified as permanent or casual.

Technical Efficiency

These are the residual from the production function shown in Table 2 Model [2]. The means, standard deviations and ranges for all these variables are given in the following table:

${ }^{10}$ Details of the creation of the price indices and capital stock series can be found in Teal (2000b). 
Appendix Table 1 Means, standard deviations and ranges for the investment data Number of observations $=538$ Mean Std Dev

Minimum

Maximum

Investment/Capital $(\mathrm{t}-1)$

0.06

0.15

0.00

1.18

$\Delta$ Real value-added/Capital ${ }_{(\mathrm{t}-1)}$

$-0.12$

2.30

$-14.62$

1.70

$-1.46$

13.31

Real profits/Capital ${ }_{(\mathrm{t}-1)}$

1.07

1.32

9.63

Education/Employee

10.30

0.69

6.73

Tenure/employee ${ }_{(t-1)}$

1.97

1.54

17.03

Real Debt/Capital $(\mathrm{t}-1)$

4.91

3.77

0.08

24.12

Technical Efficiency

0.11

0.44

0.00

4.52

0.008

0.97

$-2.71$

2.51 